\title{
ВІКТИМОЛОГІЧНІ ЗАХОДИ ЗАПОБІГАННЯ КОРИСЛИВО-НАСИЛЬНИЦЬКИМ ЗЛОЧИНАМ В УКРАЇНI
}

\author{
СЕМЕНИШИН Микола Олександрович - кандидат юридичних наук, \\ докторант Донецького юридичного інституту МВС України \\ DOI:10.32782/EP.2020.2.16 \\ УДК 343.915
}

У статті розроблені та запропоновані заходи віктимологічного запобігання корисливонасильнищьким злочинам, які спрямовуються на захист потениійної та реальної жертв. На основі результатів аналізу зарубіжного досвіду та багаторічної вітчизняної практики запропоновано прийняти кримінологічну програму запобігання корисливо-насильницьким злочинам, у якій визначено пріоритетні завдання підрозділів Начіональної полічій (кримінальної та патрульної поліиій, превентивної діяльності) на основі стратегї випередження злочинних діянь, з урахуванням оперативних можливостей та аналізу оперативної обстановки на території обслуговування. Запропоновано методику виявлення потенційних жертв (уже використовують підрозділи превентивної діяльності Начіональної полічії), яка включає програми (алгоритми) дій, спрямовані на виявлення осіб, схильних до вчинення корисливо-насильницьких злочинів, та їх зв'язків, а також осіб (їх груп) з підвищеним рівнем віктимності.

Ключові слова: корисливо-насильницькі злочини, жертва, віктимологічне запобігання, Національна полічія Украӥни.

Постановка проблеми

Прискорення процесів європейської інтеграції України потребує впровадження у правоохоронну практику не лише сучасних форм і методів протидії злочинності, а й визнаних світовим співтовариством стандартів захисту прав і свобод людини. Реальні демократичні перетворення є невід'ємними від гуманізації соціальних відносин, адже людина, іiі життя і здоров'я, честь та гідність, недоторканність і безпека визнаються найвищою соціальною цінністю.

На розвиток українського суспільства початку XXI ст. впливає декілька груп чинників, зокрема наслідки демонтажу соціалістичної моделі розвитку країни (зростання соціальної незахищеності, втрата ціннісних орієнтирів, різке зниження рівня життя, збільшення маргінальної маси за рахунок безробітних, бездомних та інших категорій населення, які перебувають за межею бідності); складна соціально-політична ситуація (військові дії у східних областях, покращення технічної оснащеності злочинців, зростання рівня нетерпимості, девальвація морально-правових цінностей); вплив тенденцій глобалізованого світу (аномізація суспільства на рівні глибинних параметрів існування та відтворення соціуму; посилення міграційних процесів та позицій транснаціональної організованої злочинності), що в комплексі створюють підгрунтя для виникнення нових типів кримінальних загроз для населення i, відповідно, сприяють його інтенсивній віктимізації.

Ужиті правоохоронними та іншими державними органами заходи не дали можливості нейтралізувати основні внутрішні та зовнішні загрози національній безпеці, що зумовлюють подальше ускладнення криміногенної ситуації в державі в умовах гібридної війни. Так, за останні десять років рівень злочинності зріс більше ніж у чотири 


\section{Кримінальне право, кримінальний процес та криміналістика}

рази, зокрема збільшилася питома вага найнебезпечніших іiі проявів. Зокрема, у 2019 році кількість громадян, які стали жертвами кримінальних посягань, збільшилася на 9,0 \% та становила 400,7 тис. (у 2015 році - 366,3 тис.). Серед потерпілих від злочинів майже 156,8 тис. жінок, 29,2 тис. пенсіонерів, 5,8 тис. дітей, 1,8 тис. іноземців, 194 працівники засобів масової інформації. Понад 5,6 тис. осіб загинуло. Найбільш незахищеними верствами населення залишаються жінки та діти (за 2015-2019 роки збільшилася майже на чверть кількість корисливонасильницьких діянь за ст.ст. 115, 149, 187 Кримінального кодексу України), а також особи похилого віку, щодо яких у 2019 році вчинено на 5,3 \% більше кримінальних правопорушень, ніж у попередні періоди [1; 2].

\section{Аналіз останніх досліджень і публікацій}

Окремі аспекти поведінки жертви злочинів, її правового захисту, заходи віктимологічного запобігання висвітлювали представники української(В.В.Голіна, Б. М. Головкін, О. М. Джужа, В. О. Туляков), радянської та російської (К. В. Вишневецький, В. І. Задорожний, Д. В. Рівман, В. Я. Рибальська, В. І. Полубинський, В. С. Устинов, А. В. Франк), західноєвропейської (М. Вольфганг, Р. Гассер, I. Маттес, Х. Нагель, Б. Станков, А. Фаттах, Б. Холист, Г. Шнайдер), американської (Ф. Вертхам, К. Сйкбєpi, С. Кормен, Т. Кук, Р. Мертон, Т. Тайлер, Дж. Фарелл, Ж. Флеммінг) віктимологічних наукових шкіл.

Доктринальні положення, сформульовані зазначеними авторами, мають важливе наукове і практичне значення. Водночас низка питань визначення характеру і змісту віктимологічного запобігання корисливонасильницьким злочинам в Україні залишається невирішеною.

\section{Основні результати дослідження}

Історія розвитку суспільства свідчить про те, що рівень злочинності зростає тоді, коли в державі складається кризова ситуація. Загострення соціально-економічного становища в країні, перехід до ринкових відносин, лібералізація цін, різке зниження життєвого рівня більшості населення, майнове розшарування в суспільстві призвели до зростання рівня корисливої злочинності. За останні роки кримінальна ситуація в Україні характеризується різким загостренням. Аналіз деяких показників злочинності, таких як кримінальна віктимізація (ії рівень, масштаби, наслідки) та кримінальна активність (соціально-групова поширеність), свідчить про зростання кримінального напруження в суспільстві [3, с. 3].

В умовах різкого погіршення кримінальної ситуації необхідне розроблення ефективної державної програми щодо боротьби зі злочинністю 3 включенням до неї достатніх, часом нестандартних, запобіжних заходів, що вимагає підвищення професійного рівня працівників правоохоронних органів.

Корисливо-насильницькі злочини завдають істотної шкоди населенню. За кожним iз цих злочинів стоїть трагедія, яка обумовлена не тільки матеріальними втратами, а й моральною шкодою. Особи втрачають почуття впевненості у своїй безпеці та збереженні майна, що негативно позначається на їх життєдіяльності [4, с. 107]. Усе це зумовлює необхідність пошуку шляхів покращення запобіжної роботи правоохоронних органів у сфері боротьби 3 розглянутими злочинами.

Як показує практика, важливу роль у вчиненні корисливо-насильницьких злочинів відіграє також не тільки необачна та некритична, а навіть провокуюча поведінка, яка заснована на психологічних особливостях особи жертви [5, с. 252; 6, с. 210$].$ Головною причиною вчинення розглянутих злочинів є певна спрямованість й особливості психологічних властивостей особи потерпілого, що виразилися в необережній, аморальній, або протиправній поведінці. При цьому не можна розглядати властивості особи потерпілого та їі поведінки окремо від об'єктивних чинників, тобто таких зовнішніх умов, які, взаємодіючи з особою та поведінкою жертви, призводять до вчинення злочину. Облік об'єктивних чинників у ситуації вчинення злочину відіграє важливу роль, тому що вони багато в чому сприяють вчиненню таких злочинів, при яких відсутній прямий психічний контакт між жертвою 
та злочинцем (наприклад незаконне заволодіння автотранспортом). У даному випадку факторами, що сприяють вчиненню злочину, виступають соціальні умови, соціальне середовище, економічне становище жертви [7, с. 394].

Виходячи з отриманих у ході даного дослідження результатів, можемо констатувати, що головними завданнями віктимологічного запобігання корисливо-насильницьким злочинам 6 : 1) захист потенційної жертви - недопущення вчинення стосовно неї корисливо-насильницького злочину; 2) захист реальної жертви: припинення стосовно неї злочинних дій; недопущення вчинення нового злочину; допомога у відновленні їі прав.

Для їх реалізації варто здійснити наступні заходи.

1. Розробити комплексну цільову програму, визначення нових шляхів та резервних можливостей у запобіганні злочинності. Зокрема, таким резервом буде зміна традиційного підходу до проблеми запобігання злочинам як проблеми прямого впливу не тільки на злочинців, а й на потенційних і реальних жертв. Необхідно якомога повніше залучати громадян, 3МІ до запобігання таких злочинів.

У цьому контексті необхідно інформувати все населення про способи вчинення злочину, здійснювати аналіз віктимізації за місцем, часом, вчиненням корисливо-насильницьких злочинів. 3 урахуванням класифікації і типології жертв важливо інформувати громадян про те, хто найчастіше й унаслідок яких обставин і ситуацій стає жертвою таких посягань.

2. Удосконалити діяльність відповідних підрозділів Національної поліції (підрозділів кримінальної поліції, превентивної діяльності і т. ін.). Для запобігання таким злочинам зазначені підрозділи повинні виконувати більший обсяг функцій, ніж вони виконують сьогодні. У зв'язку з цим, необхідно застосовувати такі заходи організаційного характеру, як розширення функції підрозділів кримінальної поліції й превентивної діяльності, або створення спеціальних підрозділів 3 покладанням на них завдань запобігання злочинам, виявлення та про- ведення запобіжної роботі з потенційними жертвами. Ці функції має бути спрямовано на випередження злочинних діянь з урахуванням оперативних можливостей кримінальної поліції.

3. Видозмінити зміст спеціальної віктимологічної підготовки працівників поліції. На практиці виникає багато проблем психологічного, правового характеру, тому інформація про осіб, які можуть стати жертвою злочину через певні обставини, дасть змогу працівникам правоохоронних органів здійснювати більш ефективну запобіжну роботу.

За результатами проведеного дослідження можна запропонувати таку методику виявлення потенційних жертв, що включає в себе напрями виявлення:

а) від особи, яка схильна до вчинення корисливо-насильницького злочину, - шляхом встановлення і вивчення її кола зв'язків слід визначити коло потенційних потерпілих (наприклад, сусід-збоченець (грабіжник, хуліган, який вже притягався до кримінальної відповідальності, мав чи має судимість), проживає один в ізольованій квартирі (будинку), може мати зв’язки із сусідськими дітьми, підлітками, отже, існує ймовірність вчинення ним стосовно них злочину. Або раніше судимий за крадіжку, грабіж чи розбійний напад сусід, який зловживає наркотиками або спиртними напоями, товаришуе із сусідами, відвідує їх у квартирі, що дає можливість за слушної нагоди вчинити крадіжку);

б) від конкретної особи шляхом вивчення даних кримінальної статистики щодо потерпілих можна встановити конкретну особу чи групу осіб з підвищеним рівнем віктимності (наприклад, на певній території проживає раніше неодноразово засуджений за корисливо-насильницькі злочини, який вчинив низку злочинів (крадіжки, вимагання, грабежі) у своєму та сусідніх будинках. Причому щодо деяких потерпілих злочини вчинялися два - три рази. Встановити особи потерпілих, яким чином проникав злочинець до їх приміщень, які засоби застосовував, що викрадав.

Соціальному середовищу, що визначає людську поведінку, формує їі світогляд та інтереси, не завжди належить головна роль у процесі детермінації. В основі причинного 


\section{Кримінальне право, кримінальний процес та криміналістика}

комплексу конкретного злочину знаходяться як криміногенна ситуація, так і негативні психологічні деформації, що прийняли форму суспільно небезпечної установки особистості. Негативні соціальні якості та вади особистості особливо гостро проявляються під час кризових моментів розвитку суспільства.

4. 3 метою оцінки реальної криміногенної ситуації і необхідно організувати громадські центри допомоги жертвам та свідкам, у яких, крім правової, повинна надаватися ще й психологічна допомога потерпілим. Іншими словами, використовуючи методи психологічного тестування, необхідно визначати психологічні особливості їх особи, що, на нашу думку, дозволить певній частині населення усвідомити свою поведінку, щоб не стати потерпілими.

5. Активно ознайомлювати громадян із сучасними засобами технічного та фізичного захисту від можливого проникнення до будинку, квартири, іншого приміщення, автівки (кнопки термінового виклику поліції, охоронна сигналізація, відеокамери спостереження, відеодомофони та ін.). При цьому важливу роль у запобіганні корисливо-насильницьким злочинам мають відігравати правові заходи, які пов'язані з кримінальноправовим захистом потерпілих. Але факти фізичної розправи і психічного тиску на потерпілих $з$ метою примушення останніх відмовитися або давати помилкові свідчення свідчать про низьку ефективність реалізації сучасних правових норм. Це підтверджується й вивченням судової практики - вироків, що набрали законної сили, за якими прослідковується невідповідність винесеного покарання і ступеня суспільної небезпеки злочину, оскільки ці діяння - це замах не тільки на нормальну діяльність органів правосуддя, а й на життя, здоров'я, гідність потерпілого, який повторно стає жертвою злочинного посягання [6, с. $301 ; 8$, с. 322$]$.

За результатами проведеного нами дослідження визначено, що важливим заходом запобігання корисливо-насильницьким злочинам 6 встановлення особливого порядку відшкодування збитків потерпілим, залежно від поведінки та ролі останніх у вчиненні злочину. Зокрема, за даними проведених кримінологічних досліджень стосовно по- терпілих від корисливо-насильницьких посягань, тільки у 8\% випадків збиток було відшкодовано повністю, у 52\% випадків відшкодовано частково, а в $40 \%$ - не відшкодовано взагалі.

Таке становище спричиняє відсутність віри громадян в ефективність діяльності правоохоронних органів щодо захисту їх майнових інтересів. Невипадково $70 \%$ опитаних не виявляють достатньої активності в захисті своїх майнових інтересів.

Як показали результати даного дослідження, важливе значення в запобіганні корисливо-насильницьким злочинам повинно відігравати індивідуальне віктимологічне запобігання, що полягає у виявленні осіб з підвищеною віктимністю і проведенні 3 ними захисних та виховних заходів, спрямованих на зниження ризику стати жертвою злочинних посягань [9, с. 22].

У спеціальній літературі викладено різні прийоми і методи індивідуального віктимологічного запобігання [10;11]. Однак ці заходи зводяться лише до захисної та виховної роботи з громадянами, які вже стали потерпілими. Робота з виявлення осіб з підвищеною віктимністю практично не здійснюеться. Така однобічність індивідуального віктимологічного запобігання зумовлена, головним чином, відсутністю спеціальних методик 3 виявлення осіб з підвищеною віктимністю та суб'єктів, які здійснюють цей специфічний вид запобігання.

Система заходів індивідуального віктимологічного запобігання має деякі особливості, оскільки під час його здійснення відбувається не просто «дія активного суб'єкта на пасивний об'єкт, а специфічна форма міжособового зв'язку, в якому одна сторона прагне трансформувати, перетворити поведінку іншої»[12, с. 127].

Враховуючи отримані у ході даного дослідження результати, заходи індивідуального запобігання можемо поділити на два види: заходи переконання і заходи допомоги.

Заходи переконання мають як захисний, так і виховний характер. Заходами переконання є бесіди, роз'яснення, як не стати жертвою злочину, яким чином забезпечити збереження свого майна. Стосовно потен- 
ційних жертв нейтрального або пасивного типу з метою формування в них обачності, обережності, уважності необхідно застосовувати заходи індивідуального віктимологічного запобігання.

У результаті проведеного нами дослідження визначено, що однією 3 важливих умов зниження рівня віктимності потенційних жертв є їх правове навчання. Зокрема, знання законів, що регулюють цивільні, кримінально-правові, господарські відносини, дасть змогу уникнути нелегкої долі жертви злочину.

Більше того, індивідуальне віктимологічне запобігання має резервні можливості для запобігання корисливо-насильницьким злочинам і разом із застосуванням вищезазначених заходів та за допомогою розроблення й реалізації конкретних рекомендацій щодо виявлення потенційних жертв, прогнозування їх віктимної поведінки та зниження потенційної віктимності $\boldsymbol{\epsilon}$ ефективним важелем у віктимологічному запобіганні загалом [13, с. 139].

Враховуючи зазначене та 3 метою індивідуального запобігання корисливо-насильницьким злочинам, варто запропонувати дві взаємопов'язані програми: 1) програма виявлення осіб з підвищеною віктимністю; 2) програма корекції віктимності окремих громадян.

Мета першої програми полягає у виявленні ступеня віктимності в окремих громадян і прогнозуванні їх віктимної поведінки. При цьому варто зазначити, що виявлення осіб $з$ підвищеною віктимністю, тобто тих, хто потребує запобіжного впливу, є по суті прогнозуванням їх індивідуальної віктимної поведінки. Існують думки, що таке прогнозування дуже складне $[7$, с. 398; 14 , с. $313 ; 15$, с. $155 ; 16 ; 17$, с. $70 ; 18$, с. 85-86]. На наш погляд, якщо зібрати інформацію, якість та обсяг якої будуть достатні для визначення ступеня віктимності громадянина, то з'явиться можливість передбачити в подальшому його віктимну поведінку. Обсяг та якість інформації повинні обумовлюватися вивченням не тільки соціально-демографічних ознак конкретної особи (стать, вік, соціальний стан тощо), правових ознак (правова культура, рецидив жертви), а й ві- домостями, що характеризують особу та іï поведінку.

Виявивши певний ступінь віктимності й ознак, що визначають вірогідність ії розвитку в майбутньому, необхідно, використовуючи заходи індивідуального віктимологічного запобігання, знизити високий потенціал віктимності конкретної особи. Для цього необхідно застосувати другу програму 3 корекції віктимності окремих громадян. Програма корекції (зниження) віктимності, що діє відповідно до завдань індивідуального віктимологічного запобігання, повинна здійснюватися у двох формах - безпосередній та ранній.

Безпосереднє запобігання спрямоване на особу, яка стала жертвою злочину або перебуває у стані, близькому до перетворення на жертву. Раннє запобігання спрямоване на особу, яка підпадає під ознаки потенційної жертви.

3 метою виявлення потенційних жертв, зниження потенціалу їх віктимності слід орієнтувати органи Національної поліції, насамперед, на активізацію роботи 3 населенням. У цьому аспекті необхідно використовувати заходи допомоги: організувати спеціальні консультативні пункти, центри соціально-психологічної захисту громадян від злочинів, головним завданням яких має стати інформування населення про заходи захисту від усіх злочинів. На пунктах і в центрах психологічної допомоги необхідно організувати «групові» та «індивідуальні» консультації з потенційними жертвами злочинів, у процесі проведення яких надавати їм соціально-психологічну допомогу, прогнозувати їх індивідуальну віктимну поведінку, виявляти та намагатися разом з ними нейтралізувати віктимологічно значущі риси особи й особливості поведінки [19, с. 144 148].

Завдання підвищення ефективності участі правоохоронних органів у реалізації заходів загального віктимологічного та особливо індивідуального віктимного запобігання зумовлює необхідність вирішення низки управлінських проблем, що стосуються створення спеціального (по роботі 3 потерпілими) запобіжного апарату в системі Національної поліції України, зокрема 


\section{Кримінальне право, кримінальний процес та криміналістика}

Управління запобігання злочинам Департаменту превентивної діяльності Національної поліції України.

Кримінологічний аналіз корисливо-насильницьких злочинів свідчить про те, що дані злочини мають високий ступінь суспільної небезпеки, оскільки заподіюють не тільки значних матеріальних збитків потерпілому, а й завдають йому моральну шкоду, породжуючи невпевненість, страх за себе, близьких, за свою власність. Особи, які вчиняють зазначені вище злочини, характеризуються глибокою соціальною деградацією і соціальною зараженістю. Володіючи високим професіоналізмом, вони виявляють потенційних жертв і реалізують свій злочинний задум.

Саме тому ефективність запобігання корисливо-насильницьким злочинам разом 3 іншими загальними заходами соціальноекономічного характеру передбачає включення до досліджуваних кримінологічних характеристик злочинів їх жертв, що зумовить дещо інший підхід до визначення як напрямів запобіжної роботи загалом, так і організації віктимологічного запобігання конкретним злочинам; розроблення запобіжних заходів щодо потенційних реальних жертв злочинів і включення їх до цільових загальнодержавних та регіональних програм запобігання і боротьби зі злочинністю; розширення соціальних і правових гарантій безпеки потерпілих та розроблення механізму відшкодування шкоди потерпілому, заподіяної корисливо-насильницьким злочином 3 урахуванням віктимологічної оцінки його ролі.

Загалом, на правоохоронні органи має бути покладено завдання 3 розроблення й упровадження системи поточного статистичного обліку віктимологічних показників злочинності, що надасть диференційоване уявлення про потерпілих від злочину.

\section{Висновки}

Таким чином, заходи віктимологічного запобігання корисливо-насильницьким злочинам спрямовуються на захист потенційної та реальної жертв. На сьогодні актуальним видається прийняття кримінологічної програми запобігання корисливо-насильниць- ким злочинам, у якій визначити пріоритетні завдання підрозділів Національної поліції на основі практики західноєвропейських країн «стратегії випередження» 3 урахуванням оперативних можливостей та аналізу оперативної обстановки на певній території. Також варто розробити методику виявлення потенційних жертв, спрямовану на виявлення осіб, схильних до вчинення корисливо-насильницьких злочинів, та їх зв'язків, а також осіб (груп) з високим рівнем віктимності. Розроблено програму корекції віктимності осіб, спрямовану на особу, яка стала жертвою злочину або перебуває у стані, близькому до перетворення на жертву, а також яка має ознаки потенційної жертви.

\section{Аітература}

1. Вплив соціально-економічних процесів на злочинність в Україні та у світі (за офіційними матеріалами $\mathrm{OOH}$, Всесвітнього банку, статистичного органу Евросоюзу (Eurostat), Державної служби статистики України): аналітичний огляд. Київ: ДНДІ МВС України, 2020. 34 с.

2. Про зареєстровані кримінальні правопорушення та результати їх досудового розслідування. Генеральна прокуратура України. URL: http://www.gp.gov.ua/ua/stat.html.

3. Ситковский А. $\lambda$. Виктимологическая характеристика и профилактика корыстных преступлений против собственности граждан: монография. Москва: ВНИИ МВД России, 1998. 108 с.

4. Мінченко С. I., Піщенко Г. I.Віктимологічні аспекти негативних соціальних явищ, пов'язаних із злочинністю. Право України. 2006. № 5. С. 107-111.

5. Віктимологія: навч. посіб. / за заг. ред. В. В. Голіни, Б. М. Головкіна. Харків: Право, 2017. 308 с.

6. Кримінологічна віктимологія: навч. посіб. / Моiсеєв С. М., Джужа О. М., Василевич В. В. та ін.; за заг. ред. проф.О. М. Джужі. Київ: Атіка, 2006. 352 с.

7. Джужа А. О. Теоретичні та практичні засади віктимологічного запобігання злочинам в Україні: дис...докт. юрид. наук: 12..00.08. Харків, 2018. 662 с.

8. Головкін Б. М. Корислива насильницька злочинність в Україні: феномен, де- 
термінація, запобігання: монографія. Харків: Право, $2011.431 \mathrm{c.}$

9. Алексеев А. И., Герасимов С. И., Сухарев А. Я. Криминологическая профилактика: теория, опыт, проблемы. монография. Москва: Изд-во НОРМА, 2001. 496 с.

10. Криминология: учебник для вузов / под общ. ред. А. И. Долговой. 3-е изд., перераб. и доп. Москва: Норма, 2005. 912 с.

11. Бандурка О. М., Аитвинов О. М. Протидія злочинності та профілактика злочинів: монографія. Харків: Харк. нац. ун-т внутр. справ, 2011. 308 с.

12. Саркисов Г. С. Индивидуальная профилактика преступлений: учеб. пособ. Ереван: Айастан, 1986. 184 с.

13. Полубинский В. И., Ситковский А. $\Lambda$. Теоретические и практические основы криминальной виктимологии: монография. Москва: ВНИИ МВД России, 2006. 291 с.

14. Ривман Д. В., Устинов В. С. Виктимология: учебник. СПб.: Юридический центр Пресс, 2000. 332 с.

15. Варчук Т. В. Виктимологическое моделирование в криминологии и практике предупреждения преступности: монография. Москва: Юнити-Дана: Закон и право, 2012. 239 c.

16. Туляков В. О. Вчення про жертву злочину: соціально-правові основи: автореф. дис. ... докт. юрид. наук: 12.00.08. Одеca, 2001. 37 c.

17. Литвинов О. М. Кримінологічні прогнозування і планування в координації діяльності суб'єктів профілактики злочинів. Вісник Харківського начіонального університету внутрішніх справ. 2001. Спец. вип. С. 69-74.

18. Блажівський С. М. Моніторинг протидії злочинності в Україні: монографія. Харків: Золота миля, 2013. 372 с.

19. Басков А.В.Виктимологическая профилактика корыстно-насильственных преступлений, совершаемых в общественных местах: автореф. дисс. на соиск. учен. степени канд. юрид. наук: спец. 12.00.08 «Уголовное право и криминология; уголовно-исполнительное право». Москва: ВНИИ МВД России, 2010. 180 с.
У статті розроблені та запропоновані заходи віктимологічного запобігання корисливо-насильницьким злочинам, які спрямовуються на захист потенційної та реальної жертв.

В умовах різкого погіршення кримінальної ситуації необхідне розроблення ефективної державної програми щодо боротьби зі злочинністю $з$ включенням до неї достатніх, часом нестандартних, запобіжних заходів, що вимагає підвищення професійного рівня працівників правоохоронних органів. У зв'язку з чим, на основі результатів аналізу зарубіжного досвіду та багаторічної вітчизняної практики розроблено проєкт програми запобігання корисливо-насильницьким злочинам, визначено пріоритетні завдання підрозділів Національної поліції (кримінальної та патрульної поліції, поліції охорони) на основі стратегії випередження злочинних діянь, $з$ урахуванням оперативних можливостей та аналізу оперативної обстановки на території обслуговування. Запропоновано методику виявлення потенційних жертв (уже використовують підрозділи превентивної діяльності Національної поліції), яка включає програми (алгоритми) дій, спрямовані на виявлення осіб, схильних до вчинення корисливо-насильницьких злочинів, та їх зв'язків, а також осіб (їх груп) з підвищеним рівнем віктимності.

Важливе значення в запобіганні корисливо-насильницьким злочинам повинно відігравати індивідуальне віктимологічне запобігання, що полягає у виявленні осіб з підвищеною віктимністю і проведенні 3 ними захисних та виховних заходів, спрямованих на зниження ризику стати жертвою злочинних посягань. Індивідуальне віктимологічне запобігання має резервні можливості для запобігання корисливо-насильницьким злочинам і разом із застосуванням вищезазначених заходів та за допомогою розроблення й реалізації конкретних рекомендацій щодо виявлення потенційних жертв, прогнозування їх віктимної поведінки та зниження потенційної віктимності є ефективним важелем у віктимологічному запобіганні загалом.

Враховуючи зазначене та 3 метою індивідуального запобігання корисливо-насильницьким злочинам, запропоновано дві 


\section{Кримінальне право, кримінальний процес та криміналістика}

взаємопов'язані програми: програма виявлення осіб з підвищеною віктимністю; програма корекції віктимності окремих громадян.

Ключові слова: корисливо-насильницькі злочини, жертва, віктимологічне запобігання, Національна поліція України.

\section{VICTIMOLOGICAL MEASURES FOR PREVENTING MURDER-VIOLENGE IN UKRAINE}

The article develops and proposes victimprevention measures for acts of violence and violence aimed at protecting potential and actual victims.

In the context of a sharp deterioration of the criminal situation, it is necessary to develop an effective state program for combating crime with the inclusion of sufficient, sometimes nonstandard, preventive measures in it, which requires the improvement of the professional level of law enforcement officials. In connection with this, on the basis of the results of the analysis of foreign experience and many years of domestic practice, a draft program for the prevention of selfish and violent crimes was developed, the priorities of the units of the National police (criminal and patrol police, police protection) were determined based on the strategy of crime prevention, taking into account opera- tional capabilities and analysis of the operational situation in the service area. A methodology for identifying potential victims (already used by the National Police Preventive Action Units) is proposed, which includes programs (algorithms) for actions aimed at identifying persons liable to commit acts of self-violence and their relationships, as well as persons (their groups) with increased level of victimization.

Individual victim victim prevention, which is to identify persons with increased victimization and to take protective and educational measures aimed at reducing the risk of becoming a victim of criminal offenses, should play an important role in preventing selfish and violent crimes. Individual victim prevention has the potential to prevent self-inflicted acts of violence and, together with the implementation of the aforementioned measures, through the development and implementation of specific recommendations for identifying potential victims, predicting their victim behavior and reducing potential victimization, is an effective tool for preventing victimization.

In view of this, two interrelated programs have been proposed and for the purpose of individual prevention of acts of violence and violence: a program for identifying persons with high levels of victimization; a program to correct the victimization of individual citizens.

Keywords: selfish-violent crimes, victim, victim-prevention, National Police of Ukraine. 